\title{
Evidence for a mitochondrial lineage originating from the Arabian peninsula in the Madagascar house mouse (Mus musculus)
}

\author{
J-M Duplantier ${ }^{1,4}$, A Orth ${ }^{2}$, J Catalan ${ }^{3}$ and F Bonhomme ${ }^{2}$ \\ ${ }^{1}$ Programme RAMSE, IRD (ex ORSTOM), Madagascar; ${ }^{2}$ Laboratoire Génome Populations Interactions (UMR5000 CNRS- \\ Université Montpellier 2), Université Montpellier 2, 34095 Montpellier cedex 5; ${ }^{3}$ Laboratoire Génétique et Environnement, ISEM \\ (UMR 5554 CNRS-U.M.2), CC 065, Université Montpellier 2, 34095 Montpellier cedex 5
}

\begin{abstract}
Various subspecies of the house mouse (Mus musculus sensu lato) are known to have contributed to its worldwide expansion. However, the origin of mice on some larger islands such as Madagascar has remained unknown, with several sources being possible. In order to classify the Malagasy house mouse, individuals were trapped in 13 different localities distributed throughout the island. For 33 individuals the control region (D-Loop) of the mitochondrial DNA was partially sequenced and 21 males were typed for a Zfy-2 polymorphism of the $Y$ chromosome. Malagasy mt DNA lineages constitute a narrow monophyletic group which sug-
\end{abstract}

gests a recent and probably single origin, and are very close to the gentilulus mitochondrial lineages from Yemen. This was supported by the fact that all the males have the domesticus type $\mathrm{Y}$ chromosome, like gentilulus. From these results, it can be inferred that the Malagasy house mice originate probably from the Arabian peninsula in a single colonisation wave, unlike its human population. Our results provide a better molecular description of the Yemeni-Malagasy mitochondrial clade which clearly belongs to the Mus musculus radiation.

Heredity (2002) 89, 154-158. doi:10.1038/sj.hdy.6800122

Keywords: mitochondrial D-Loop; Y chromosome; Mus musculus; colonisation; gentilulus; Madagascar

\section{Introduction}

With a surface area of $587000 \mathrm{~km}^{2}$, Madagascar is the fourth largest island on Earth. It was separated from the African continent 160 million years ago and the minimum distance from Africa is presently $300 \mathrm{~km}$. The first known human settlements are approximately 1500 years old. Important waves of immigration occurred just 1000 years ago (Battistini and Verin, 1973). The current human population originated from Asia (Indonesia) and from Africa.

At least 23 species of rodents currently inhabit Madagascar (Rakotondravony and Randrianjafy, 1998). Apart from the three cosmopolitan species introduced by humans as they have been elsewhere, ie the black rat, the Norway rat and the house mouse, all rodents belong to one endemic sub-family: the Nesomyinae. Today, the black rat is the most abundant and the most widespread rodent on the island and is responsible for causing the extinction of endemic rodents (Goodman, 1995). The house mouse is present in human dwellings throughout the country but is less abundant than the black rat. It can also be encountered in the countryside (rice fields, savannas, borders of marshes) but at very low densities.

Correspondence: Dr JM Duplantier

${ }^{4}$ Present address: CBGP, Campus International de Baillarguet, CS 30016, 34988 Montferrier sur Lez cedex, France.

E-mail : duplant@ensam.inra.fr

Received 29 October 2001; accepted 18 April 2002
The house mouse (Mus musculus species complex) originated from the Indian subcontinent (Boursot et al, 1996; Din et al, 1996). It is assumed that it radiated approximately 0.5 million years ago in three directions, thus giving rise to the current subspecies (which some authors consider as proper species, see Sage et al, 1993) : Mus musculus domesticus in Western Europe and the Mediterranean Basin, M. m. musculus in Central Europe and northern China, M. m. castaneus in Southeast Asia. The status of the populations from the source region is unresolved, they are sometimes regarded as belonging to $M$. $m$. castaneus, or even as a fourth taxon, M. m. bactrianus. More recently, Prager et al (1998) suggested that a gentilulus lineage may exist on the Arabian peninsula (which would represent a subspecies according to the nomenclature adopted in the present article, but a species according to the original article), based on a divergent mitochondrial lineage recently described in Yemen.

To this day, the house mouse in Madagascar has always been referred to as M. musculus (Rakotondravony and Randrianjafy, 1998) or as M. m. domesticus (Boursot et al, 1993). No substantive morphological or genetic study has ever been conducted on the mice of Madagascar. However, Rakotondravony and Randrianjafy (1998) indicated that these mice always have a tail about as long as head and body. This trait seems to be characteristic of the domesticus taxon (species, sub- or semi-species) (Marshall, 1998). Hence, the aim of the present study was to establish the taxonomic position of Malagasy house mice in order to document their geographic origin and 
to evaluate the age of the colonization. Interestingly, our results can be compared with recently published data on the colonisation of Madeira island (Gunduz et al, 2001) which occurred, at most, 600 years ago.

\section{Materials and methods}

While studying the role of rodent populations as plague reservoirs in the Madagascar High Plateaus, mice were captured in different localities. They were captured inside houses using 'Sherman' traps or wire-meshed traps. We recorded the standard body measurements of all adult mice. After death, the spleen was removed to test for the plague bacillus (all negative), and other organs (kidneys, liver, heart) were finely chopped and conserved in $90 \%$ ethanol for subsequent DNA extraction. Thirty-three individuals from 13 different localities were analysed in the present study (Table 1).

Total DNA was extracted from each individual according to a standard protocol. The control region (D-Loop) of the mitochondrial DNA was amplified along its entire length by PCR using the primers MTL2 : ${ }^{5}$ AGCATTTTCAGTGCTTTGCT ${ }^{3}$, position H41, and MTL3 : ${ }^{5}$ CACCACCAGCACCCAAAGCT $^{3 \prime}$, position L15372, designed after the M. m. domesticus sequence of Bibb et al (1981). These fragments were directly sequenced on an ALF-AP Automated Sequencer (Pharmacia). For 15 individuals, the sequences were long enough so that 539 nucleotides located in the $5^{\prime}$ portion of the D-Loop (position 15424-15960) could be aligned using the MULTALIN program (Corpet et al, 1988). After adding reference sequences representing different taxa from the subgenus Mus (see legend to Figure 1) a phylogenetic tree was inferred by maximum likelihood with 500 bootstrap replicates, using the program DNAML in the PHYLIP package (Felsenstein, 1993).

The two types of $\mathrm{Y}$ chromosomes characterising the different M. musculus subspecies (Nagamine et al, 1992) can be differentiated by the presence (in musculus and castaneus) or absence (in domesticus, gentilulus and the Indian-Pakistani populations) of a 18 base pair section in the last exon of the $Z f y 2$ gene. In order to determine the type to which the Malagasy mice belong, we used the same protocol as Orth et al (1996).

Standard karyotypes were obtained for eight $F_{1}$ indi-

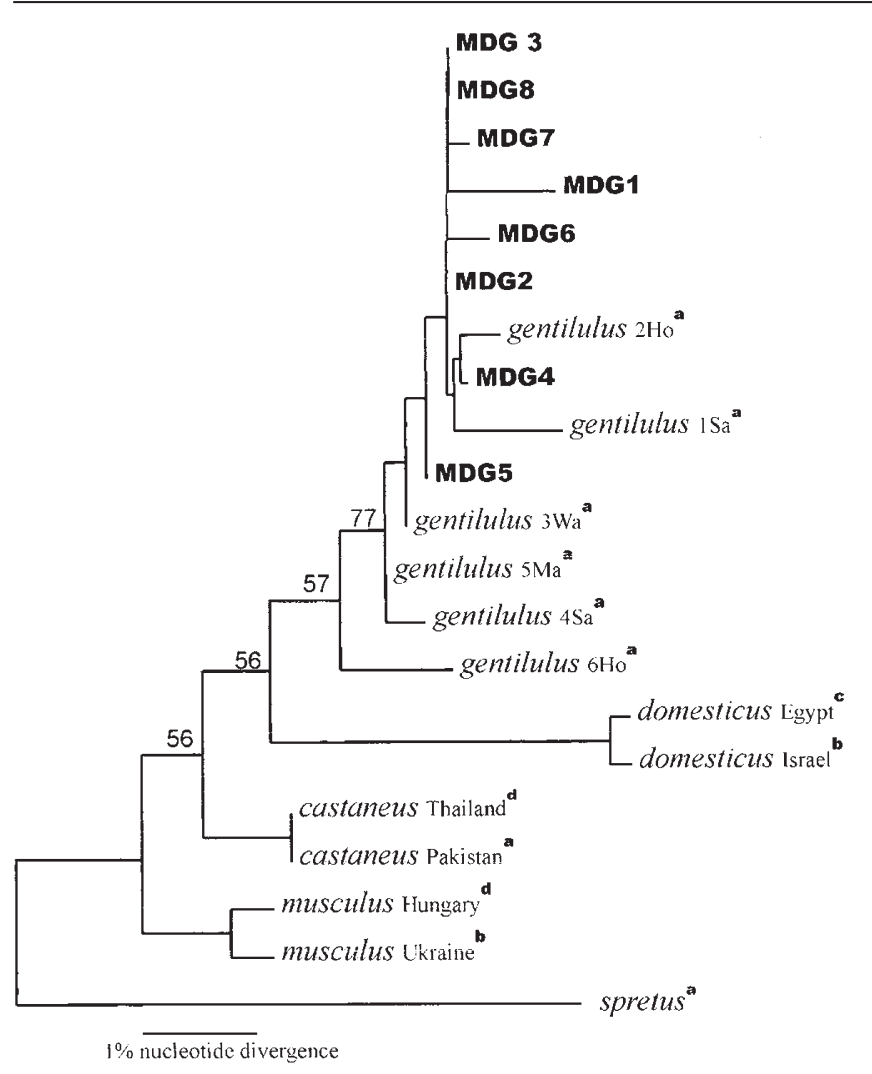

Figure 1 Phylogeny of the mitochondrial DNA haplotypes. The tree is rooted with the Mus spretus sequence. Branch lengths are calculated by maximum likelihood and the bootstrap values are obtained after 500 resampling. Bold : Malagasy haplotypes : MDG1 [Antananarivo]; MDG2 [Firarazana, Ambodifaho and 2 Manakasina]; MDG3 [Ambodifaho]; MDG4 [Ampadratokana]; MDG5 [Kamolandy]; MDG6 [Mahajanga]; MDG7 [Antafotenona]; MDG8 [Nanarena, Ampadratokana, Ambalatenona and 2 Manakasina; (see Table 1 for geographic references of localities). Italics: reference populations from: ${ }^{\text {a }}$ Prager et al, 1998, 'Prager et al, 1996, 'Prager et al, 1993, 'present study).

viduals from five pairs of wild parents trapped in Manakasina (locality 2 , Table 1), using the air drying method on bone marrow preparations after yeast stimulation (Lee and Elder, 1980). G banding and karyotype analyses were performed according to the method of Seabright (1971)

Table 1 Geographic origin and composition of each sample

\begin{tabular}{|c|c|c|c|}
\hline Locality & Latitude / Longitude & No. of adults trapped & No. of adults analysed \\
\hline 1 Antananarivo & $18^{\circ} 54^{\prime} \mathrm{S}, 47^{\circ} 31^{\prime} \mathrm{E}$ & $10 \mathrm{~m} / 31 \mathrm{f} *$ & $2 \mathrm{f}$ \\
\hline 2 Manakasina & $18^{\circ} 56^{\prime} \mathrm{S}, 47^{\circ} 56^{\prime} \mathrm{E}$ & $21 \mathrm{~m} / 75 \mathrm{f} *$ & $8 \mathrm{~m} / 6 \mathrm{f}$ \\
\hline 3 Ambodifaho & $18^{\circ} 49^{\prime} \mathrm{S}, 49^{\circ} 03^{\prime} \mathrm{E}$ & $3 \mathrm{~m} / 1 \mathrm{f}$ & $2 \mathrm{~m}$ \\
\hline 4 Firarazana & $18^{\circ} 08^{\prime} \mathrm{S}, 47^{\circ} 13^{\prime} \mathrm{E}$ & $1 \mathrm{~m}$ & $1 \mathrm{~m}$ \\
\hline 5 Kamolandy & $17^{\circ} 30^{\prime} \mathrm{S}, 46^{\circ} 58^{\prime} \mathrm{E}$ & $1 \mathrm{~m} / 2 \mathrm{f}$ & $2 \mathrm{~m}$ \\
\hline 6 Mahajanga & $15^{\circ} 43^{\prime} \mathrm{S}, 46^{\circ} 18^{\prime} \mathrm{E}$ & $21 \mathrm{~m} / 39 \mathrm{f} *$ & $2 \mathrm{~m}$ \\
\hline 7 Antafotenona & $21^{\circ} 12^{\prime} \mathrm{S}, 48^{\circ} 02^{\prime} \mathrm{E}$ & $2 \mathrm{~m} / 2 \mathrm{f}$ & $2 \mathrm{~m}$ \\
\hline 8 Ambalatenona & $21^{\circ} 12^{\prime} \mathrm{S}, 48^{\circ} 15^{\prime} \mathrm{E}$ & $3 \mathrm{~m} / 6 \mathrm{f}$ & $1 \mathrm{~m}$ \\
\hline 9 Ampadratokana & $22^{\circ} 22^{\prime} \mathrm{S}, 46^{\circ} 05^{\prime} \mathrm{E}$ & $8 \mathrm{~m} / 13 \mathrm{f}$ & $1 \mathrm{~m} / 1 \mathrm{f}$ \\
\hline 10 Nanarena & $22^{\circ} 30^{\prime} \mathrm{S}, 45^{\circ} 45^{\prime} \mathrm{E}$ & $9 \mathrm{~m} / 21 \mathrm{f} *$ & $2 \mathrm{~m}$ \\
\hline 11 Carion & $18^{\circ} 54^{\prime} \mathrm{S}, 47^{\circ} 42^{\prime} \mathrm{E}$ & $9 \mathrm{~m} / 20 \mathrm{f} *$ & $2 \mathrm{~m}$ \\
\hline 12 Manjakandrina & $18^{\circ} 55^{\prime} \mathrm{S}, 47^{\circ} 48^{\prime} \mathrm{E}$ & $3 \mathrm{~m}$ & $2 \mathrm{~m}$ \\
\hline 13 Ambalamanakana & $20^{\circ} 44^{\prime} \mathrm{S}, 47^{\circ} 10^{\prime} \mathrm{E}$ & $1 \mathrm{~m}$ & $1 \mathrm{~m}$ \\
\hline Total & & $93 \mathrm{~m} / 210 \mathrm{f} *$ & $24 \mathrm{~m} / 9 \mathrm{f}$ \\
\hline
\end{tabular}

*Sex-ratio significantly different from $1 / 1$. 
and the nomenclature of Cowell (1984). Observations were made with a Zeiss Axiophot microscope and karyotyping was performed by image analysis using the Genevision software (Applied Imaging).

\section{Results}

In all localities where over 20 adult individuals were captured, and in the entire sample of captured animals, there was a significant bias in favour of females (Table 1). There was no significant difference between males and females for any of the lengths measured. But, due to a large number of pregnant females in our sample, there was a difference in weight (females: mean $=13.9 \mathrm{~g}$, $\min / \mathrm{Max}=7 / 30 \mathrm{~g}, n=210$; males: $\operatorname{mean}=11.9 \mathrm{~g}$, $\mathrm{m} / \mathrm{M}=7 / 18 \mathrm{~g}, n=93$ ). The external morphology of these Malagasy adult mice could be summarised as follows: (i) head and body length: mean $=78.1 \mathrm{~mm}, \min / \mathrm{Max}$ $=58 / 97 \mathrm{~mm},(n=302)$; (ii) tail length: mean $=77.4 \mathrm{~mm}$, $\mathrm{m} / \mathrm{M}=62 / 91 \mathrm{~mm}, \quad(n=283) ; \quad$ (iii) ear length: mean $=12.8 \mathrm{~mm} ; \mathrm{m} / \mathrm{M}=9 / 16 \mathrm{~mm},(n=295)$; (iv) hindfoot length (su): mean $=16.1 \mathrm{~mm} ; \mathrm{m} / \mathrm{M}=12 / 19 \mathrm{~mm}$, $(n=300)$. The length of the tail is practically identical to the length of head and body (mean $=99 \%$ of head and body length, $\mathrm{m} / \mathrm{M}=80 \% / 121 \% ; n=283$ ).

Regarding the mitochondrial lineages: the $33 \mathrm{mt}$ DNA haplotypes for which we had a minimum of $294 \mathrm{bp}$ sequences clearly belonged to the same lineage (not shown). Among the 15 individual sequences spanning the complete 539 bp fragment, eight haplotypes could be identified (GenBank accession numbers AY091517AY091526 ). The tree in Figure 1 expresses their phylogenetical relationships to other $M$. musculus reference haplotypes. The robustness of the nodes is indicated by their bootstrap values. Figure 1 clearly shows that all individuals analysed share a common matriline very close to the gentilulus lineages described by Prager et al (1998). The bootstrap values including gentilulus lineages from Yemen are not very high given the large number (197) of non-determined sites according to which these sequences were aligned, the Prager et al sequences, produced from museum specimens, being incomplete. The nucleotide divergence for the 15 Malagasy sequences over the $540 \mathrm{bp}$ was estimated at $0.32 \%$. If sequences of the same region are taken (as available in Genebank) inside Mediterranean M. m. domesticus $(n=7)$, a divergence is obtained of $0.77 \%$ and $0.83 \%$ in Eastern European M. m. musculus $(n=7)$. If the six Yemeni sequences are now considered, a $1.5 \%$ divergence is obtained (over only $323 \mathrm{bp}$ ). The preceeding values over the same nucleotides become $0.37 \%, 0.79 \%$ and $1.39 \%$ for Madagascar, M. m. domesticus and M. m. musculus respectively, clearly indicating that the nucleotide divergence is smaller in Madagascar than among the continental subspecies.

The 21 males analysed all possessed a fragment of $202 \mathrm{bp}$ which is characteristic of the typical domesticus $\mathrm{Y}$ chromosome, which is also the case for gentilulus from Yemen (Prager et al, 1998).

Chromosomal data show that all individuals show a diploid number of 40 acrocentric chromosomes characteristic of the whole subgenus Mus (Boursot et al, 1993) and chromosomal identification by $\mathrm{G}$ banding analyses conformed with the standard band pattern described by Cowell (1984) for the house mouse.

\section{Discussion}

The female-biased sex-ratio observed here is common in commensal populations and high-density populations (Auffray, 1988), while outdoor populations usually have an excess of males (Ritte et al, 1992; Chatti et al, 1999), as do low-density populations (Sage, 1981).

From a morphological point of view and particularly with respect to the ratio of tail length to length of head plus body, the measurements from Malagasy mice are in the range of the domesticus subspecies (Orsini et al, 1983), however this ratio is also similar (0.99 vs 0.97) in Yemeni mice classified as belonging to the gentilulus subspecies (Prager et al, 1998). The Malagasy mice seem larger than the former, however we only considered adults while Marshall (1998) considered that all individuals collected in Yemen (the same as in Prager et al, 1998) were immature; furthermore the Yemeni sample is very small $(n=6)$, and does not allow us to perform a more detailed morphological comparison.

No differences were found between the banding pattern of Malagasy mice and previous results published by Hsu et al (1978) for several species (domesticus, molossinus, caroli, cervicolor, cookii, booduga) belonging to subgenus Mus which has a karyotype known to be highly conservative; the presence of an HSR (homogeneously staining region) is not detected in Malagasy mice, but has been observed in different 'domesticus' populations by Hübner et al (1994).

Previous studies (Boursot et al, 1996; Boissinot and Boursot, 1997; Prager et al, 1998) revealed the existence of four major mitochondrial lineages: the domesticus lineage, the musculus lineage, the 'oriental' lineage (including castaneus and the central populations of the Indian subcontinent), and the gentilulus lineage, identified in Yemen. With the results from the present study we can identify two main characteristics in the Malagasy population of mice. Firstly, the Malagasy and Yemeni individuals are very close phylogenetically. Secondly, the Malagasy mitochondrial lineage consists of one very narrow monophyletic group within which it is difficult to find subgroupings between sequences from different populations analysed on the island, which indicates a recent and probably unique origin of these lineages as attested by the low nucleotide diversity observed.

We can therefore imagine that the Malagasy monophyletic lineage originated from the Arabian peninsula. This is consistent with the information obtained regarding the $\mathrm{Y}$ chromosome which could also stem from the same source. One single and relatively recent colonisation event could thus explain the data we obtained.

While the history of the colonisation of Europe by the house mouse is well documented (for instance, Auffray et al, 1990), this is not the case for Madagascar. However, the kinship between the Yemeni mice and those from Madagascar argues in favour of importation along the African coast and from the islands of Pemba, Zanzibar and the Comoros, as previously described for the shrew Suncus murinus by Hutterer and Tranier (1990). This shrew originated from Asia: it is naturally present from Pakistan to Japan. Its expansion westwards, to the Arabian peninsula, the coast of East Africa and the islands of the Indian Ocean is the result of importations by humans. Hutterer and Tranier (1990) noted that all capture localities for S. murinus, in Arabia, the Red Sea, in Africa 
and in Madagascar, are situated along historical navigation pathways of Arabic merchants and in particular of dhows from the sultanate of Oman. Along the African coast, these pathways ran all the way down to Sofala in Mozambique, then crossed the Mozambique canal towards Madagascar and went on to Mauritius. This hypothesis seems corroborated for the mouse by archeological excavations: bony remains identified as belonging to M. musculus and to Rattus rattus were found in Mahilaka (in the north-east of Madagascar), an Islamic port dating back to the 11th to 14th centuries (Rakotozafy, 1996).

Hutterer and Tranier (1990) noted a very high morphological variability within the shrew populations from the Arabic peninsula and from Africa (including Madagascar) and suggested that they could be the result of multiple importations from different origins. Note that our results for the mouse do not follow the same pattern. In Madagascar there is low genetic diversity and there is no trace of genes from Southeast Asia nor from elsewhere. Despite our sampling included rural villages as well as a large harbour (Mahajanga) and the largest urban settlement on the island (the capital Antananarivo), the $33 \mathrm{mt}$ DNA haplotypes for which we had a minimum of 294 bp sequences were clearly belonging to a unique clade.

Indeed, a contribution of the type castaneus from Indonesia could have been expected, since the human migrations from this archipelago were numerous in the past (Battistini and Vérin, 1973). Yet neither the mitochondrial lineages nor the $\mathrm{Y}$ chromosome appears to have originated from there. If individuals belonging to M. m. domesticus and M. m. musculus subspecies have been imported in the past and until today by ships coming from Asia and Europe, which is probable, no detectable contribution of these taxa appear in our sample. The initial colonisation must therefore have been quite rapid and probably stemming from very few females, with the first occupants on the scene preventing eventual subsequent migrants from bringing any detectable genetic contribution.

A similar phenomenon was recently reported for another island, Madeira, known to have been colonised by humans and mice 600 years ago (Gunduz et al, 2001). These authors report the nucleotide sequence of a stretch of the D-loop slightly longer, but encompassing ours, for 15 haplotypes derived from 34 individuals. If only the DNA stretch common to both studies is considered (540 bp), the nucleotidic diversity is $0.19 \%$ for Madeira, while it reaches $0.32 \%$ on our data set. The Malagasy diversity is thus $1.7 \times$ higher than the Madeiran one. Given that the divergence of this last island is about 600 years, this would correspond in our case to a value around 1000 years since population expansion. This seems to fit well with what is known about the human colonisation on this island (Battistini and Vérin, 1973). The presence of man on Madagascar dates back to 1500 years, from Africa and Indonesia, while Arabian trading posts were installed on the northern and western coasts between the 8th and 11th century A.D., probable time of arrival of the house mouse on the island.

\section{Acknowledgements}

Field work in Madagascar was funded by the IRD (Institut de Recherche pour le Développement, ex ORSTOM), the Institut Pasteur de Madagascar and the Malagasy Ministry of Health (National Plague Program). We would like to thanks S Rahelinirina and M Rakotoarinosy for technical assistance in the field and JB Searle for the Madeiran frequency data.

\section{References}

Auffray JC (1988). Le commensalisme chez la souris domestique: origine, écologie et rôle dans l'évolution chromosomique de l'espèce. PhD Thesis, University of Montpellier 2, 170 p.

Auffray JC, Vanlerberghe F, Britton-Davidian J (1990). The house mouse progression in Eurasia: a paleontological and archaeozoological approach. Biol J Linn Soc 41: 13-25.

Battistini R, Verin P (1973). Man and the environment in Madagascar: past problems and problems of today. In: Battistini R, Richard-Vindard G (eds) Biogeography and Ecology in Madagascar, Jung: The Hague. pp 311-337.

Bibb MJ, Van Etten RA, Wright CT, Walberg MW, Clayton DA (1981). Sequence and gene organisation of mouse mitochondrial DNA. Cell 26: 167-180.

Boissinot S, Boursot P (1997). Discordant phylogeographic patterns between the $Y$ chromosome and mitochondrial DNA in the house mouse : selection on the Y chromosome? Genetics 146: 1019-1034.

Boursot P, Auffray JC, Britton-Davidian J, Bonhomme F, (1993). The evolution of the house mouse. Annu Rev Ecol Syst 24: 119-152.

Boursot P, Din W, Anand R, Darviche D, Dod B, Von Deimling $F$ et al (1996). Origin and radiation of the house mouse: mitochondrial DNA phylogeny. J Evol Biol 9: 391-415.

Chatti N, Ganem G, Benzkri K, Catalan J, Britton-Davidian J, Said K (1999). Microgeographical distribution of two chromosomal races of house mice in Tunisia: pattern and origin of habitat partitioning. Proc R Soc Lond B 266: 1561-1569.

Corpet F (1988). Multiple sequence alignment with hierarchical clustering. Nucl Acids Res 16: 10881-10890.

Cowell JK (1984). A photographic representation of the variability of G-banded structure of the chromosomes of the house mouse. Chromosoma 89: 294-320.

Din W, Anand R, Boursot P, Darviche D, Dod B, Jouvin-Marche $\mathrm{E}$ et al (1996). Origin and radiation of the house mouse: clues from nuclear genes. J Evol Biol 9: 519-539.

Felsenstein J (1993). Phylogeny inference package. Department of Genetics, University of Washington. Seattle.

Goodman SM (1995). Rattus on Madagascar and the dilemma of protecting the endemic rodent fauna. Conserv Biol 9: 450-453.

Gunduz I, Auffray JC, Britton-Davidian J, Catalan J, Ganem G, Ramalhinho MG et al (2001). Molecular studies on the colonization of the Madeiran archipelago by house mice. Mol Ecol 10: 2023-2029.

Hsu TC, Markvong A, Marshall JT (1978). G-band patterns of six species of mice belonging to subgenus Mus. Cytogenet Cell Genet 20: 304-307.

Hübner R, Maddalena T, Searle J, Vogel P (1994). The HSR on chromosome 1 of the house mouse, Mus domesticus: distribution and frequency in Switzerland. Genet Res Camb 64: 107-114.

Hutterer R, Tranier M (1990). The immigration of the Asian house shrew (Suncus murinus) into Africa and Madagascar. In: Peters G, Hutterer R (eds) Vertebrates in the Tropics, Museum Alexander Koenig: Bonn. pp 309-319.

Lee MR, Elder FFB (1980). Yeast stimulation of bone marrow mitosis for cytogenetic investigations. Cytogenet Cell Genet 26: 36-40.

Marshall JT (1998). Identification and scientific names of Eurasian house mice and their european allies, subgenus Mus 
(Rodentia, Muridae). Unpublished report, National Museum of Natural History, Washington.

Nagamine CM, Nishioka Y, Moriwaki K, Boursot P, Bonhomme F, Lau YFC (1992). The musculus-type Y chromosome of the laboratory mouse is of Asian origin. Mammalian Genome 3: 84-91.

Orsini P, Bonhomme F, Britton-Davidian J, Croset H, Guerasimov S, Thaler L (1983). Le complexe d'espèces du genre Mus en Europe centrale et orientale. II Critères d'identification, répartition, caractéristiques écologiques. Z. f. Säugetierkunde 48: 86-95.

Orth A, Lyapunova E, Kandaurov A, Boissinot S, Boursot P, Vorontsov N et al (1996). L'espèce polytypique Mus musculus en Transcaucasie. C.R. Acad Sci Paris 319: 435-441.

Prager EM, Sage RD, Gyllenstein U, Thomas WK, Hubner R, Jones CS et al (1993). Mitochondrial DNA sequence diversity and the colonization of Scandinavia by house mice from East Holstein. Biol J Linn Soc 50: 85-122.

Prager EM, Tichy MH, Sage RD (1996). Mitochondrial DNA sequence variation in the eastern house mouse, Mus musculus: comparison with other house mice and report of a 75-bp tandem repeat. Genetics 143: 427-446.

Prager EM, Orrego C, Sage RD (1998). Genetic variation and phylogeography of central Asian and other house mice, including a major new mitochondrial lineage in Yemen. Genetics 150:, 835-861.

Rakotondravony ADS, Randrianjafy RV (1998). Espèces introduites et endémiques de Madagascar: description, répartition, biologie et écologie. In: Zehrer W, Rafanomezana S (eds) Proceedings of Symposium " Rongeurs et lutte antimurine à Madagascar", Tamatave, 6-9 Décembre 1994, DPV/ GTZ pub, Antananarivo, Madagascar.

Rakotozafy LMA (1996). Etude de la constitution du régime alimentaire des habitants du site de Mahilaka du $\mathrm{XI}^{\circ}$ au $\mathrm{XIV}^{\circ}$ siècle à partir des produits de fouilles archéologiques. $\mathrm{PhD}$ thesis, University of Antananarivo.

Ritte U, Markman E, Neufeld E (1992). Can the variability of mitochondrial DNA distinguish between commensal and feral populations of house mouse ? Biolog J Linn Soc 46: 235-245.

Sage RD (1981). Wild Mice. In: Foster HL, Small JD, Fox JG (eds) The Mouse in Biomedical Research, Academic Press: New York, pp 39-90.

Sage RD, Atchley WR, Capanna E (1993). House mice as models in systematic biology. Systemat Biol 42: 523-561.

Seabright M (1971). A rapid banding technique for human chromosomes. Lancet 2: 971. 